\title{
Characterization and Analysis of Thionin Genes
}

\author{
F. Garcia-Olmedo, M.J. Carmona, J.J. Lopez-Fando, \\ J.A. Fernandez, A. Castagnaro, A. Molina, \\ C. Hernandez-Lucas, and P. Carbonero
}

Cátedra de Bioquimica y Biologia Molecular, E.T.S. Ingenieros Agtónomos, Universidad Politécnica de Madrid, E-28040 Madrid, Spain

\section{Contents}

I. Introduction

II. Thionin Types

III. Biosynthesis and Subcellular Location

IV. Structure and Chromosomal Location of Thionin Genes

V. Gene Expression

VI. Antimicrobial Properties and Other In Vitro Activities of Thionins
A. Alteration of Membrane Permeability
B. Inhibitory Properties
C. Possible Participation of Thionins in Thioredoxin-related Reactions

VII. Possible Implication of Thionins in Plant Defense

VIII. Conclusion and Perspectives

IX. References

\section{Introduction}

The general designation of thionins has been proposed for a family of homologous proteins that have been isolated from different tissues in a wide range of plant taxa and have been variously named purothionins, viscotoxins, crambins, etc. (see Garcia-Olmedo et al., 1989). The possible involvement of thionins in plant defense was first suggested, on the basis of their in vitro toxicity to plant pathogens, by Fernandez de Caleya et al., (1972). Those observations had been prompted by earlier reports concerning the antimicrobial properties of these polypeptides (Stuart and Harris, 1942; Balls and Harris, 1944). Work on the thionins, which has been actively pursued over the past half-century, has been recently reviewed in 
detail (Garcia-Olmedo et al., 1989). For this reason. earlier work will only be partially summarized in the present chapter, which will focus on recent developments concerning thionin genes and their potential role in plant defense mechanisms.

\section{Thionin Types}

The construction of an unrooted phylogenetic tree, following the criteria of Feng and Doolittle (1987), allowed the classification of the available amino acid sequences from the thionins (either directly determined or deduced from cDNAs) into at least four types (Garcia-Olmedo et al., 1989). The main structural features of these four types, together with those of a fifth type which has been recently discovered in our laboratory (Castagnaro et al., 1992), are summarized in Table 1.

The first type, which corresponds to that of the original purothionins isolated from wheat endosperm (Balls et al., 1942a, b), has four disulphide bridges and is highly basic, with no negatively charged residues. At least seven sequences are known of this type, and all of them have 45 amino-acid residues, 8 of which are in the central disulphide loop.

The second type is represented by thionins identified first in the leaves of the parasitic plant Pyrularia pubera (Vernon et al., 1985) and then in those of barley (Gausing, 1987; Bohlmann and Apel, 1987). This type has four disulphide bridges at the same positions as those of type I, but the molecules are less basic, with some negatively-charged residues, and their central disulphide loop has one or two more amino acid residues. As will be discussed later, the claim that barley leaf thionins can be divided into two structural groups (Reimann-Philipp et al., 1989 b) is not adequately supported by the available evidence.

The third type includes the viscotoxins and phoratoxins, mainly characterized by Samuelsson and coworkers in leaves and stems of the mistletoes (Loranthaceae), and has the following distinctive features: three disulphide bridges which are conserved with respect to the previous types; fewer basic amino acid residues; sequence with 46 residues, 9 of which are in the central disulphide loop.

A fourth type corresponds to the crambins isolated from the Abyssinian cabbage (Cruciferae) and has the same sequence length and disulphidebridge arrangement as type II, but the molecules are neutral, with a low proportion of charged amino acid residues.

The fifth type is divergent from the other four types, both in its amino acid sequence and with respect to the disulphide structure: the second and eighth cysteines of type I are missing, through point mutation and deletion, respectively, thus disrupting the first and second disulphide bridges and potentially allowing the formation of a new bridge between the unmatched cysteines. This new type, which is also neutral, has been identified in a cDNA 
Table 1. Thionin types

\begin{tabular}{|c|c|c|c|c|c|}
\hline \multirow[b]{2}{*}{ Thionin type } & \multirow{2}{*}{$\begin{array}{l}\text { Charges } \\
(+/-)\end{array}$} & \multirow{2}{*}{$\begin{array}{l}\text { Residues } \\
\text { (total/loop) }\end{array}$} & \multicolumn{2}{|l|}{ Source } & \multirow[b]{2}{*}{ References } \\
\hline & & & tissue & species & \\
\hline I & $10 / 0$ & $45 / 8$ & endosperm & $\left\{\begin{array}{l}\text { Triticum aestivum } \\
\text { Hordeum vulgare } \\
\text { Avena sativa }\end{array}\right.$ & $\begin{array}{l}\text { Othani et al., 1975, } 1977 \\
\text { Mak and Jones, 1976; Jones and Mak } 1977 \\
\text { Jones et al., 1972 } \\
\text { Ozaki et al., 1980; Ponz et al., } 1986 \\
\text { Hernandez Lucas et al., } 1986 \\
\text { Bekes and Latztity, } 1981\end{array}$ \\
\hline II & $\begin{array}{l}9 / 3 \\
7 / 1\end{array}$ & $\begin{array}{l}47 / 10 \\
46 / 9\end{array}$ & leaves & $\left\{\begin{array}{l}\text { Pyrularia pubera } \\
\text { Hordeum vulgare }\end{array}\right.$ & $\begin{array}{l}\text { Vernon et al., } 1985 \\
\text { Gausing, } 1987 \\
\text { Bohlman and Apel, } 1987\end{array}$ \\
\hline III & $\begin{array}{l}6 / 0-2 \\
5 / 1-2\end{array}$ & $46 / 9$ & $\begin{array}{l}\text { leaves and } \\
\text { stems }\end{array}$ & $\left\{\begin{array}{l}\text { Viscum album } \\
\text { Phoradendron spp. } \\
\text { Dendrophora clavata }\end{array}\right.$ & $\begin{array}{l}\text { Samuelsson, 1969,1966,1974 } \\
\text { Samuelsson et al., } 1968 \\
\text { Samuelsson and Pettersson, 1970 } \\
\text { Samuelsson and Jayarvardene, } 1974 \\
\text { Mellstrand, 1974 } \\
\text { Mellstrand and Samuelsson, 1973, } 1974 \\
\text { Thurnberg and Samuelsson, } 1982 \\
\text { Samuelsson and Pettersson, } 1977\end{array}$ \\
\hline IV & $2 / 2$ & $46 / 9$ & cotyledons & Crambe abyssinica & $\begin{array}{l}\text { Teeter et at., } 1981 \\
\text { Vermeulen et al., } 1987\end{array}$ \\
\hline V & $2 / 2$ & $38 / 9$ & endosperm & Triticum aestivum & Castagnaro et al., 1992 \\
\hline
\end{tabular}

Only charges that are at invariant positions in the different variants of a given type are represented

The central loop is that between the 4th and 5th cysteines in type I and II, or between the 3rd and 4th in the other three types 
library derived from developing wheat kernels and seems to be also present in barley.

It is to be noted that types I and II are closer to each other than to the other types, not only in their gross architecture but also at the level of the amino acid sequences, and that the same is true for types III and IV. Although the different types have been mostly investigated in particular tissues and organs of certain species or groups of related species, the observed divergence between the types can not be correlated with the evolutionary relationships among the taxa because the types defined here do not represent equivalent subsets of the protein family. Thus, types I, II, and III coexist in a single species, and the thionin isolated from Pyrulaira pubera, a parasitic plant closely related to the mistletoes, is closer to the barley-leaf thionins than to the viscotoxins and phoratoxins.

The thionins are among the best characterized proteins with respect to their three-dimensional structure, both in crystals and in solution. Because of their peculiar features they have become model molecules in the development and refinement of novel methods for the elucidation of threedimensional structures. Thus, an X-ray diffraction method based on the anomalous scattering of sulphur was specifically developed to solve the structure of crambin (Hendrickson and Teeter, 1981). This molecule was also used to test the utility of molecular dynamics with interproton distance restraints for structure determination (Brünger et al., 1986; Clore et al., $1986 \mathrm{a}, \mathrm{b}$ ), and to show that structures obtained for a protein in solution with NMR data can be used to solve the crystal structure of the same protein by molecular replacement (Brünger et al., 1987). This wealth of information, which has been recently reviewed (Garcia-Olmedo et al., 1989), indicates that types I, III, and IV, in spite of their extreme divergence, have essentially the same three-dimensional shape (Fig. 1), which resembles the Greek capital letter gamma $(\Gamma)$. The molecules are quite rigid and present very similar three-dimensional structures in solution and in crystal form. It will be of interest to elucidate the structure of type $V$ thionins.

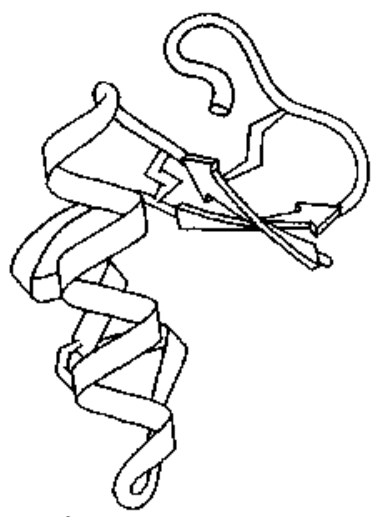

Fig. 1. Schematic drawing of the backbone of crambin. (From Whitlow and Teeter, 1985, with permission) 


\section{Biosynthesis and Subcellular Location}

Biosynthesis of thionins has been studied in some detail only in the case of type I thionins. More specifically, it has been established that barley endosperm thionins are synthesized by membrane-bound polysomes as much larger precursors that undergo at least two processing steps (Ponz et al., 1983). Using monospecific antibodies raised against the mature protein, two types of precursors were identified: one was detected as an in vitro translation product that could not be detected in vivo, and the other was detected by in vivo labelling (Fig. 2). Pulse-labelling experiments showed conversion of the second precursor into the mature protein (Fig. 3). On the basis of these experiments, Ponz et al. (1983) postulated the cotranslational excision of a signal peptide that would convert the precursor observed by in vitro translation into that observed by in vivo labelling, and at least a second, postranslational processing leading to the mature protein. As predicted from the study of their biosynthesis, the
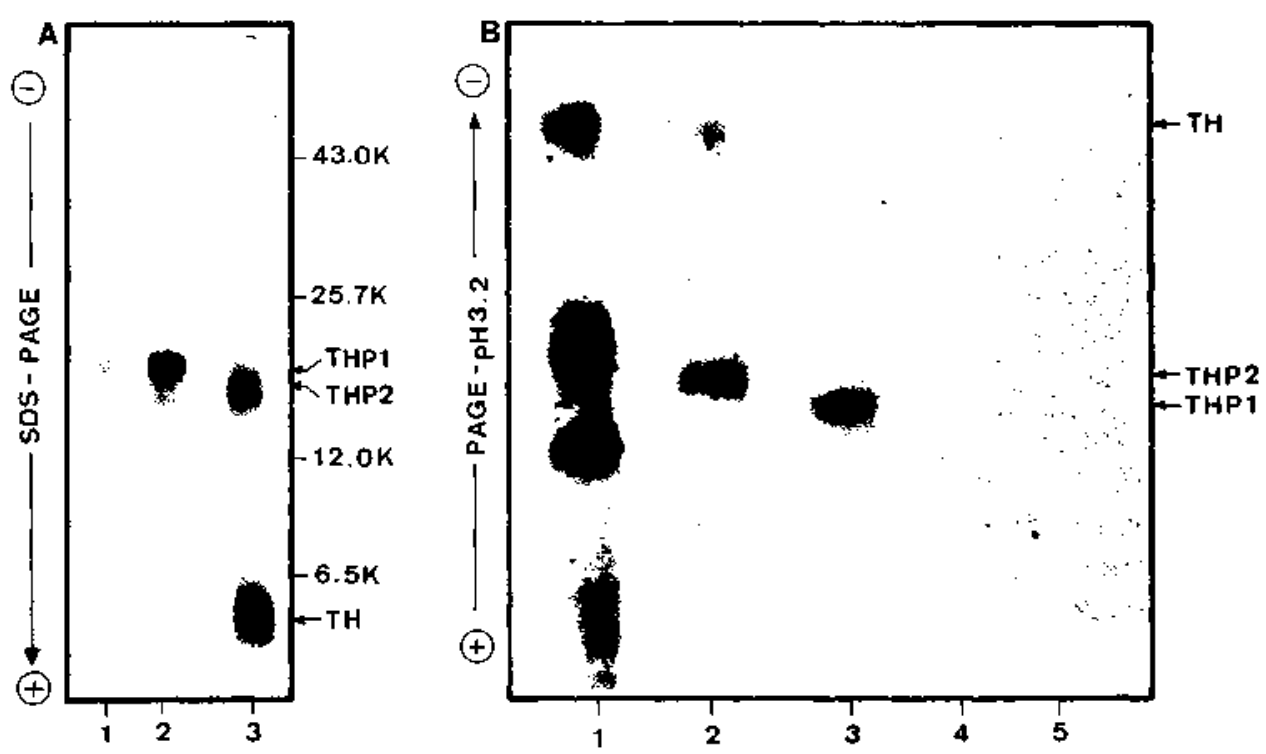

Fig. 2. Comparison of in vivo and in vitro products selected with monospecific antibodies and displacement of these products from the antigen-antibody complex by purified thionin. A, Sodium dodecyl sulphate-polyacrylamide gel electrophoresis (SDS-PAGE) of alkylated products: 1 , in vitro precursor THP 1 labelled with $\left[{ }^{35}\right.$ S $]$ methionine; 2 , as in 1 , but labelled with $\left[{ }^{35}\right.$ S $]$ cysteine; 3 , in vivo products, THP 2 and TH. B, Polyacrylamide gel electrophoresis (PAGE) at $\mathrm{pH} 3.2$ of reduced, non-alkylated products: 1 , total in vivo extracts; 2 , in vivo products, THP 2 and TH; 3 , in vitro precursor THP $1 ; 4$, as in 2 , plus $5 \mu \mathrm{g}$ of unlabelled thionin; 5 , as in 3, plus $5 \mu \mathrm{g}$ of unlabelled thionin. Displacement by non-radioactive thionin of precursors THP 1 and THP 2 (4 and 5) indicates that the antibodies recognize the same antigens in the three molecules. (From Ponz et al., 1983, with permission) 

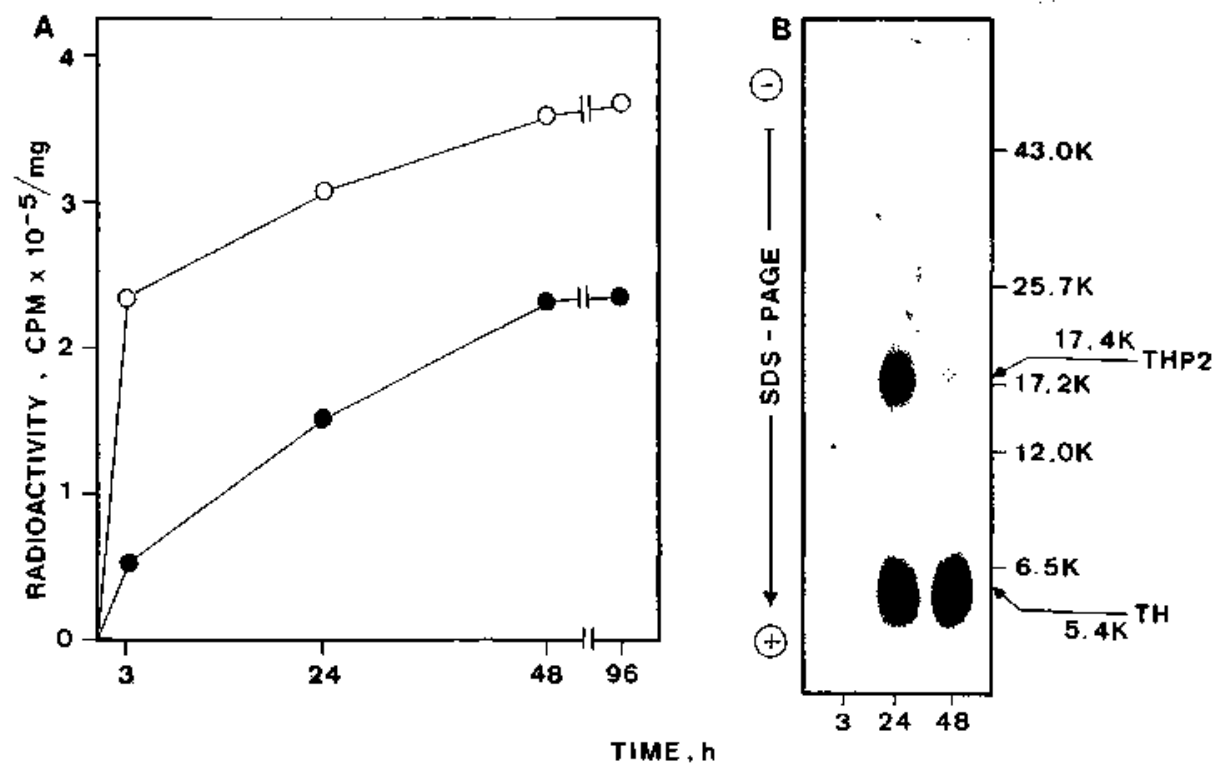

Fig. 3. Pulse-chase experiment. Time-course of $\left[{ }^{35} \mathrm{~S}_{\mathrm{SO}_{4}}^{2-}\right.$ incorporation into proteins of 20 day barley endosperm. Samples were collected at $3,24,48$, and $96 \mathrm{~h}$ after label was added. $A$, Total $(\mathrm{O}-\mathrm{O})$ and trichloroacetic acid insoluble $(-)^{35} \mathrm{~S}$ incorporated into endosperm at different times. B, Proteins immunoprecipitated with monospecific antibodies at the successive stages were alkylated and subjected to SDS-PAGE and fluorography. Purified thionin (TH) was also alkylated and run in parallel. The apparent $\mathrm{M}_{\mathbf{r}}$ of the thionin precursor (THP 2) in its alkylated form is $17,400(\mathrm{~K}=\times 1000)$. (From Ponz et al., 1983, with permission)

nucleotide sequences of the cDNAs corresponding to $\alpha$ and $\beta$ thionins from barley endosperm were found to encode precursors that were much larger than the mature proteins (Ponz et al., 1986; Hernández-Lucas et al., 1986). The deduced structures of these precursors consisted of an $\mathrm{N}$-terminal signal peptide, followed by the mature protein and a $\mathrm{C}$-terminal acidic protein, as shown in Fig. 4. The same precursor structure was later found for type-II thionins (Gausing, 1987; Bohlmann and Apel, 1987) and, more recently, for type $\mathrm{V}$ thionins (Castagnaro et al., 1992), which strongly suggests that at least these two types of thionins have the same biosynthetic pathway as type I thionins.

Preliminary cellular fractionation studies carried out with developing barley endosperm by Ponz et al. (1983), using a variety of homogenization buffers, led to the conclusion that type I thionins were intracellular and in a labile association with the particulate fraction, which could be disrupted by increasing the salt concentration or by treatment with low concentrations of non-ionic detergents. More recent localization studies, using immunogold detection by electron microscopy, have shown that type I thionins are in the periphery of the protein bodies (Carmona et al., unpubl.). 


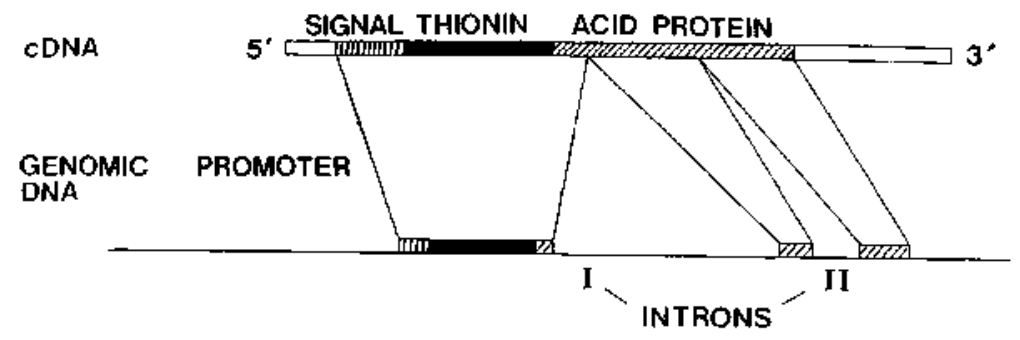

Fig. 4. Structure of the thionin precursor (Ponz et al., 1986) and of the $\alpha$-thionin gene $(H t h-I)$ from barley endosperm. (From Rodriguez-Palenzuela et al., 1988, with permission)

The final cellular localization of type II thionins remains to be established with certainty. It was first claimed that leaf thionins are exclusively located in the cell wall, based on electron micrographs of immunogoldlabelled thin sections, using an antibody raised against a fusion protein expressed in E. coli (Bohlmann et al., 1988). These authors also saltextracted thionins from cell walls after extensive washing. Subsequently, they found that about $98 \%$ of leaf thionins were intracellular and claimed that there were two distinct groups of leaf thionins: those present in the cell walls and those that are intracellular (Reiman-Philipp et al., 1989b). This claim is not sufficiently supported by the available evidence for the following reasons: (i) The partial $\mathrm{N}$-terminal amino acid sequences reported by Reiman-Philipp et al. (1989b) for the putative intracellular and the cell-wall thionins do not differ significantly. (ii) Antibodies raised against the intracellular thionins cross-reacted with the putative cell-wall ones (ReimanPhilipp et al. (1989b). (iii) In our experience, thionins are soluble in a wide variety of buffers, aqueous solutions of alcohols, and organic solvents. This can lead to relocation of the thionins during fractionation or histological preparation procedures. Moreover, the extracted thionins would be expected to bind to negatively charged groups on the cell wall from which they could be later extracted with solutions containing high concentrations of salt.

\section{Structure and Chromosomal Location of Thionin Genes}

The availability of different wheat aneuploids, and of chromosomal addition lines of wheat-rye and wheat-barley, has been extremely useful for mapping genes encoding different proteins in wheat and related species (Garcia-Olmedo et al., 1982, 1984). Three genes (Pur-A1, Pur-BI and Pur$D 1$ ), which corresponded to the $\beta, \alpha 1$, and $\alpha 2$ thionin variants from wheat endosperm (type I), respectively, were identified in the long arms of chromosomes $1 \mathrm{~A}, 1 \mathrm{~B}$ and $1 \mathrm{D}$, through the electrophoretic analysis of the 
appropriate aneuploids and the characterization of the isolated proteins (Fernandez de Caleya et al., 1976). In a similar manner, a gene for an endosperm thionin was located in the long arm of chromosome $1 \mathrm{R}$ of rye (Sanchez-Monge et al., 1979). Southern-blot analyses of genomic DNAs of wheat and barley, using type I, cDNA probes, were consistent with the presence of 1-2 gene copies of this type per haploid genome (RodriguezPalenzuela et al., 1988; unpubl. data). Type II genes have been located in chromosome $6 \mathrm{H}$ of barley by Southern-blot analysis of DNAs from wheatbarley addition lines (Bohlmann et al., 1988); but there are discrepancies as to the number of copies of this type present: while Bohlmann et al. (1988) estimated about 100 genes/haploid genome, Gausing (1988) gave a lower estimate of 9-11 genes. More recently, type $V$ genes have been located within a few kb (kilobase) of the type I genes in wheat, and their copy number per haploid genome seem to be also 1-2 (Castagnaro et al., 1992). Although the amino acid sequence of the mature type $V$ thionin is quite different from the other types, the C-terminal acidic peptide of the corresponding precursor is less divergent than the mature protein and closer to the type I than to the type II peptide.

The gene for $\alpha$-hordothionin, a type I thionin from barley endosperm, has been cloned and its complete sequence has been published (RodriguezPalenzuela et al., 1988). This gene has two introns, 420 and 91 nucleotides long, that interrupt the sequence encoding the $\mathrm{C}$-terminal, acidic peptide of the precursor (Fig. 4). Although genomic clones of type II thionins have not been described in detail, it seems that they also have two introns (Bohlmann et al., 1988).

To date genes encoding the type III and IV thionins have not been mapped nor have CDNA and genomic clones been identified.

\section{Gene Expression}

Thionin accumulation in developing barley endosperm, as judged from the intensity of stained electrophoretic bands (Fig. 5) and from pulse-labelling with $\left[{ }^{35} \mathrm{~S}_{\mathrm{SO}_{4}^{2-}}\right.$, appeared to start and to level off at earlier stages than the major storage proteins, the hordeins. This was confirmed by dot-blot hybridization analysis of the corresponding mRNA (Fig. 6), which showed a maximum steady state concentration of the messenger between 13 and 16 days after anthesis. Thus, synthesis of these proteins seems to take place during the cell-proliferation phase of endosperm development and to cease at the beginning of the cell-enlargement phase. Type I genes not only seem to be specifically expressed in barley endosperm (Fig. 6); fusions of the corresponding promoter with the $\beta$-glucuronidase (GUS) reporter gene are also specifically expressed in tobacco endosperm (Fig. 7) (Fernández et al., unpubl.). When fusions of the 35S promoter with the $\alpha$-hordothionin gene (coding regions and introns) are expressed in transgenic tobacco, the size of the mRNA generated seems to be the same as that of the mRNA resulting from 


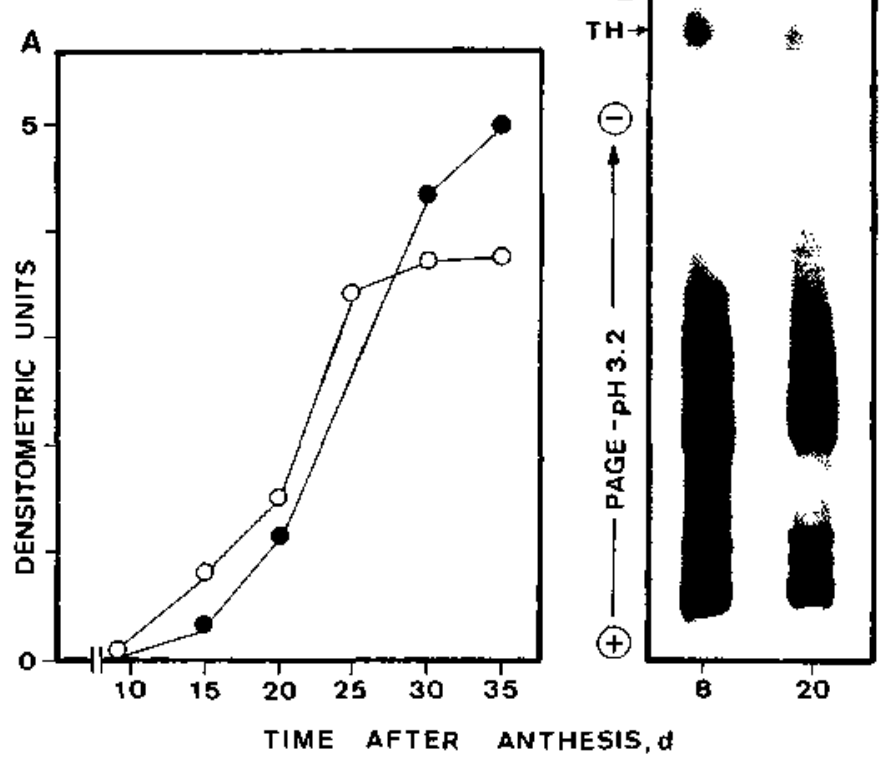

Fig. 5. Thionin synthesis during endosperm development. A, Relative amounts of thionin $(\mathrm{O}-\mathrm{O})$ were quantitated by densitometry of the stained band after PAGE pH 3.2 in endosperm samples collected at different times after anthesis. Hordeins $(\bullet-\odot)$ were similarly quantitated after SDS PAGE in the same samples. Different arbitrary scales have been used in each case. B, PAGE pH 3.2 and fluorography of endosperm extracts. Ears were collected at 8 and 20 days after anthesis, labelled for $48 \mathrm{~h}$ with $\left[{ }^{35} \mathrm{~S}_{5} \mathrm{SO}_{4}^{2-}\right.$ and freeze-dried.

Endosperms were separated by hand-dissection

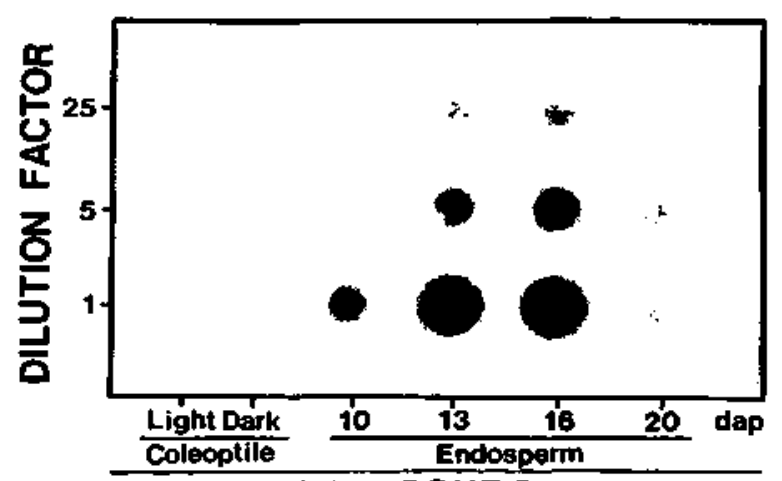

RNA SOURCE

Fig. 6. Endosperm-specific expression of the $\mathrm{Hth}$-l gene. Dot-blot hybridization of RNAs from the indicated sources with the nick-translated insert of clone pTHG 1 (Rodriguez-

Palenzuela et al., 1988). Equal amounts $(2 \mu \mathrm{g})$ of each RNA were spotted 




A

B

Fig. 7. Histochemical staining for GUS activity of hand-dissected tobacco endosperms from: A, Non-transformed control. B, Plants transformed with a fusion of the $\alpha$-hordothionin promoter $(2 \mathrm{~kb})$ with the structural part of the GUS gene. Embryos, leaves, stems, and roots

did not have any GUS activity in the transformed plant (not shown)

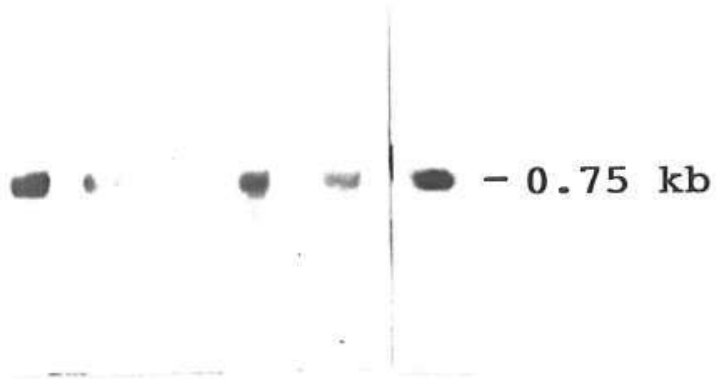

\section{$\begin{array}{llllll}1 & 2 & 3 & 4 & 5 & 6\end{array}$}

Fig. 8. Northern-blot analysis of RNA from leaves of tobacco plants transformed with fusions of the $35 \mathrm{~S}$ promoter and $\alpha$-hordothionin gene sequences. 1 and 2 , plants transformed with the coding region of an $\alpha$-hordothionin cDNA; 3 , non-transformed control; 4 and 5 , plants transformed with the coding region of $\alpha$-hordothionin genomic DNA; 6 , barley endosperm. The hybridization probe used was $\alpha$-hordothionin cDNA. 
fusions from the CDNA, which suggests that the introns from this monocot gene are properly spliced in a dicot (Fig. 8) (Carmona et al., unpubl.).

The expression of type II thionin genes has been investigated in barley leaves and a number of interesting responses of these genes to external stimuli have been described. Large amounts of messenger for type II thionins were detected in dark-grown barley seedlings (Gausing, 1987; Bohlmann and Apel, 1987). Steady state messenger levels seemed to be higher in the lower $1 / 3$ of the leaf (younger cells) than in the upper $2 / 3$ (older cells) and to decline sharply upon illumination (Gausing, 1987). The effect of light has been further investigated by Reimann-Philipp et al. (1989a), who have postulated the mediation of two photoreceptors, phytochrome and a blue-light-absorbing photoreceptor. Synthesis of thionins concomitantly ceased upon illumination, but the previously accumulated thionin was rather stable (Reiman-Philipp et al., 1989a). The inhibitory effect of light can be overcome by stress- and pathogen-induced signals, as it has been shown that fungal infection induces a transient expression of the thionin genes in the leaves (Bohlmann et al., 1989; Ebrahim-Nesbat et al., 1989) and that the chlorides of divalent cations $\left(\mathrm{Mg}^{2+}, \mathrm{Mn}^{2+}, \mathrm{Cd}^{2+}, \mathrm{Zn}^{2+}\right)$ elicit a more permanent response (Fisher et al., 1989).

\section{Antimicrobial Properties and Other In Vitro Activities of Thionins}

The toxicity of thionins to different kinds of organisms and to cells in culture has been investigated for several decades. Gram-positive bacteria and, to a lesser extent, Gram-negative bacteria, bakers yeast, and some human pathogenic fungi were found to be sensitive to a crystalline mixture of type I thionins from wheat endosperm; whereas the mycelial fungi tested were found to be insensitive (Stuart and Harris, 1942). After these initial findings, the toxicity to bacteria (Fernández de Caleya et al., 1972), to yeast (Balls and Harris, 1944; Nose and Ichikawa, 1968; Okada et al., 1970; Okada and Yoshizumi, 1970, 1973; Hernández-Lucas et al., 1974), and to fungi (Bohlmann et al., 1988; Reiman-Philipp et al., 1989b) has been further demonstrated for thionins of types I and II. Type I thionins were also found to be toxic to mice, guinea-pigs and rabbits when injected intravenously or intra-peritoneally, but not upon oral administration (Coulson et al., 1942). Type III thionins, isolated from the leaves of the mistletoes and related species, were also found to be toxic on parenteral administration to mice and cats (see Samuelsson, 1974). At sublethal doses they produced hypotension, bradycardia and a negative inotropic effect on the heart muscle. Intraarterial administration, in higher doses, produced vasoconstriction in arteries of skin and skeletal muscle (see Samuelsson, 1974). Cytotoxic effects on cultured mammalian cells have been reported for thionins of type I (Nakanishi et al., 1979), types I and III (Carrasco et al., 1981), type II (Vernon et al., 1985) and type III (Konopa et al., 1980). It has also been 
observed that type I thionins can reversibly block myogenic differentiation of chick embryonic muscle cells in culture (Kwak et al., 1989).

Several in vitro effects of thionins, which might account for their toxic properties, have been reported; (i) alteration of membrane permeability; (ii) inhibition of macromolecular biosynthesis; and (iii) participation in red-ox reactions in connection with thioredoxins.

\section{A. Alteration of Membrane Permeability}

Leakage of intracellular material upon exposure to thionin from wheat endosperm was demonstrated in bacteria (Fernandez de Caleya, 1973). A similar effect was described in yeast by Okada and Yoshizumi (1973), while investigating the mode of action of a toxic principle from wheat and barley that was later shown to be a mixture of thionins (Ohtani et al., 1975, 1977). They further showed that this factor not only induced leakage of phosphate ions, nucleotides, amino acids, and potassium ions, but also inhibited the incorporation of sugars. The toxic effect could be reverted by certain divalent cations, such as $\mathrm{Ca}^{2+}, \mathrm{Zn}^{2+}$, or $\mathrm{Fe}^{2+}$ (Okada and Yoshizumi, 1973).

A study of the effects of endosperm thionin variants and viscotoxins on cultured mammalian cells indicated that at the minimum cytotoxic concentrations leakage of $\mathrm{Rb}^{1+}$ and of uridine occurred (Figs. 9 and 10). Concentrations of thionins that had no detectable effects on the cultured cells lead to inhibition of translation by antibiotics such as hygromycin $B$ that do not normally cross the plasma membrane (Carrasco et al., 1981). As in the case of yeast, $\mathrm{Ca}^{2+}$ and $\mathrm{Mg}^{2+}$ could revert the action of thionin.

The observed effects on the contraction of smooth muscle from the uterus of the guinea pig (Coulson et al., 1942) and of the flight muscle from insects (Kramer et al., 1979), or the sensitivity to thionins of A31 cells infected with the Moloney strain of murine leukemia virus (Tahara et al., 1979) and the blocking of myogenic differentiation in chick embryonic cells (Kwak et al., 1989), are all probably related to interactions of thionins with the cell membrane.

\section{B. Inhibitory Properties}

Apart from a partial inhibition of the milk-clotting power of papain, possibly due to interference with essential SH-groups (Balls et al., 1942), and the inhibition of $\alpha$-amylase through competition for $\mathrm{Ca}^{2+}$ (Jones and Meredith, 1982), no strong inhibition of enzyme activity has been reported for the thionins. However, they are able to inhibit macromolecular synthesis. Nakanishi et al. (1979) reported that thionins could specifically kill cells during DNA synthesis (S phase), but had little effect during the $G_{0}$ phase; and Ishii and Imamoto (cited by Ozaki et al., 1980) demonstrated 


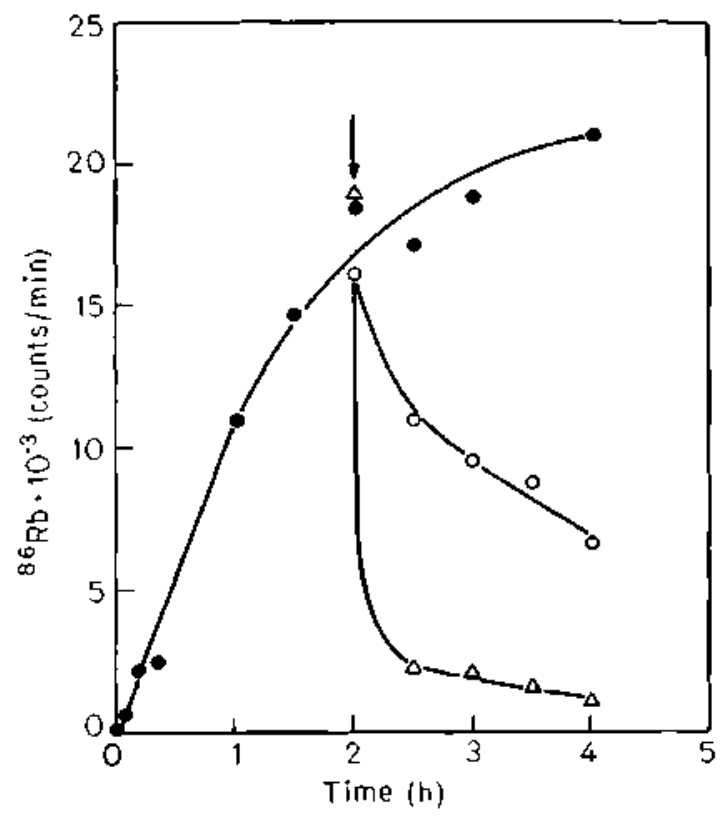

Fig. 9. Effect of thionins on the ${ }^{86} \mathrm{Rb}^{+}$content of BHK cells. ${ }^{86} \mathrm{Rb}^{+}$was estimated in the cells as indicated in Carrasco et al. (1981). The arrow indicates the time when the thionins were added. ( - ) , control; $(O-O), 1 \mu \mathrm{g} / \mathrm{ml} \alpha 1 \alpha 2 \beta$ purothionin; $(\Delta-\Delta), 1 \mu \mathrm{g} / \mathrm{ml} \alpha 1 \alpha 2 \beta$ purothionin

that thionins also inhibit the transcription of phage in Escherichia coli. The effects of endosperm thionins and viscotoxins on the synthesis of DNA, RNA, and proteins in cultured mammalian cells have been investigated by Carrasco et al. (1981). Protein synthesis was more sensitive in these cells than RNA synthesis, which in turn was more sensitive than DNA synthesis (Fig. 11). Inhibition of protein synthesis was correlated with leakage of $R b^{1+}$ from the different cell variants tested suggesting that inhibition is a direct consequence of the induced leakyness. Eucaryotic cell-free translation systems derived from wheat germ and from rabbit reticulocytes were inhibited by thionins, but at higher concentrations than in intact mammalian cells (Garcia-Olmedo et al., 1983). The inhibitory concentration varied linearly with the amount of exogenous mRNA added, which suggested a direct interaction of the toxin with the RNA (Garcia-Olmedo et al., 1983). This would be in line with the reported interaction between DNA and viscotoxins (Woynarowski and Konopa, 1980).

\section{Possible Participation of Thionins in Thioredoxin-related Reactions}

Thioredoxin, a hydrogen carrier protein that functions in DNA synthesis and in the transformation of sulphur metabolites, has been also found to serve 


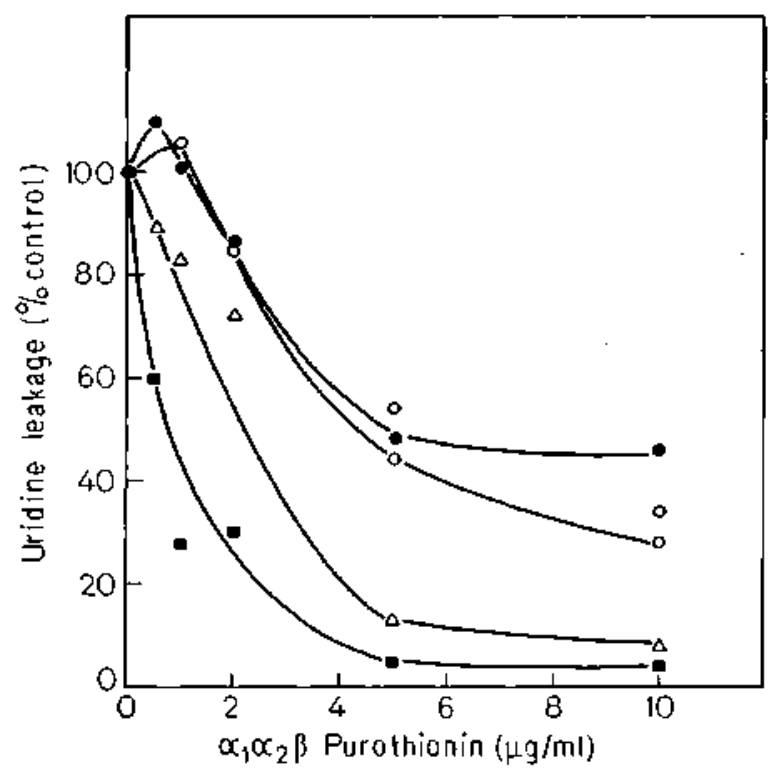

Fig. 10. Effect of thionins on the uridine pool. BHK cells grown in Linbro dishes in medium without $\mathrm{Ca}^{2+}$ and $\mathrm{Mg}^{2+} .1 \mu \mathrm{Ci}\left[5,6{ }^{3} \mathrm{H}\right]$ uridine $(48 \mathrm{Cl} / \mathrm{mmol} ; 1 \mathrm{mCl} / \mathrm{ml})$ was added per well and incubated $3 \mathrm{~h}$ at $37^{\circ} \mathrm{C}$ in the presence of $10 \mu \mathrm{g} / \mathrm{ml}$ actinomycin $\mathrm{D}$. The indicated concentration of $\alpha 1 \alpha 2 \beta$ purothionin was added, the incubation continued for $1 \mathrm{~h}$ and then the ${ }^{3} \mathrm{H}$ content as TCA soluble fraction of the cells measured $(-)(100 \%: 11942$ counts $/ \mathrm{min}), 2 \mathrm{~h}(\mathrm{O}-\mathrm{O})(100 \%: 8641$ counts $/ \mathrm{min})$, or $4 \mathrm{~h}(\triangle-\triangle)(100 \%: 7923$ counts $/ \mathrm{min})$; (a- $4 \mathrm{~h}$ incubation in the presence of purified $\beta$-thionin $(100 \%: 8437 \mathrm{counts} / \mathrm{min})$. (From

Carrasco et al., 1981, with permission)

as a regulatory protein in linking light to the activation of enzymes during photosynthesis (Buchanan et al., 1979). Thionin from wheat endosperm can substitute for thioredoxin $f$ from spinach chloroplasts in the dithiothreitollinked activation of chloroplast fructose-1,6-bisphosphatase (Wada and Buchanan, 1981). Under the standard assay conditions, thionin was only $2 \%$ as active as authentic thioredoxin $f$. Nevertheless, activity could be improved by increasing the time of preincubation and the concentration of reductant suggesting that the thionin could be effectively reduced by thioredoxin $f$ (Wada and Buchanan, 1981). This led to experiments which implicate thionins in plant redox metabolism. Johnson et al. (1987) have reported a thioredoxin system, consisting of a homogeneous preparation of thioredoxin $h$ and partially purified thioredoxin reductase (NADPH), which effectively reduced thionin with NADPH as the hydrogen donor. The reduced thionin, in turn, was capable of activating fructose-1,6-bisphosphatase. These results suggest a possible role of thionins as secondary thiol messengers in the redox regulation of enzymes. In the opinion of these authors, the redox properties of thionins could also explain their toxicity. 


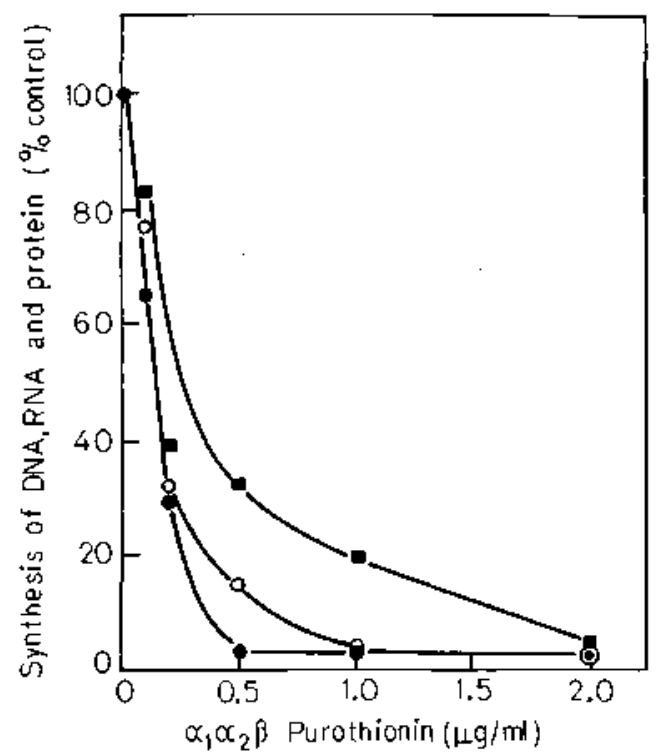

Fig. 11. Effect of thionins on macromolecular synthesis in BHK cells. Thionins were added to BHK cells in (type) medium without $\mathrm{Ca}^{2+}$ and $\mathrm{Mg}^{2+}$. After $4 \mathrm{~h}$ of incubation. DNA synthesis (a-口) (100\%: 67586 counts/min), RNA synthesis $(0-0)(100 \%: 14287$ counts/min) and protein synthesis $(-100 \%: 39934$ counts/min) were estimated. (From Carrasco et al., 1981, with permission)

\section{Possible Implication of Thionins in Plant Defense}

The hypothesis that thionins might play a role in the protection of plants against pathogens was proposed by Fernandez de Caleya et al. (1972), who investigated the susceptibility to wheat endosperm thionins of phytopathogenic bacteria in the genera Pseudomonas, Xanthomonas, Agrobacterium, Erwinia, and Corynebacterium. Minimal inhibitory concentrations (MIC) ranged from $2 \times 10^{-7} \mathrm{M}$ to $10^{-5} \mathrm{M}$ and the minimal bactericidal concentrations were usually twice the MIC. Purified genetic variants of these thionins differed in activity and showed some degree of specificity. More recently, Bohlmann et al. (1988) have shown that both endosperm (type I) and leaf (type II) thionins from barley inhibit the fungi Thielaviopsis paradoxa, a pathogen of sugar cane, and Drechslera teres, a pathogen of barley, but at concentrations of $5 \times 10^{-4} \mathrm{M}$, i.e., several orders of magnitude higher than the concentration required for the most sensitive bacteria. Recently, we surveyed the sensitivity of fungal pathogens to purified genetic variants of type $I$ thionins and found MIC values in the $10^{-6}-10^{-5} \mathrm{M}$ range, i.e., concentrations similar to those found in certain plant tissues (Fig. 12) (Molina and Fraile, unpubl.). 


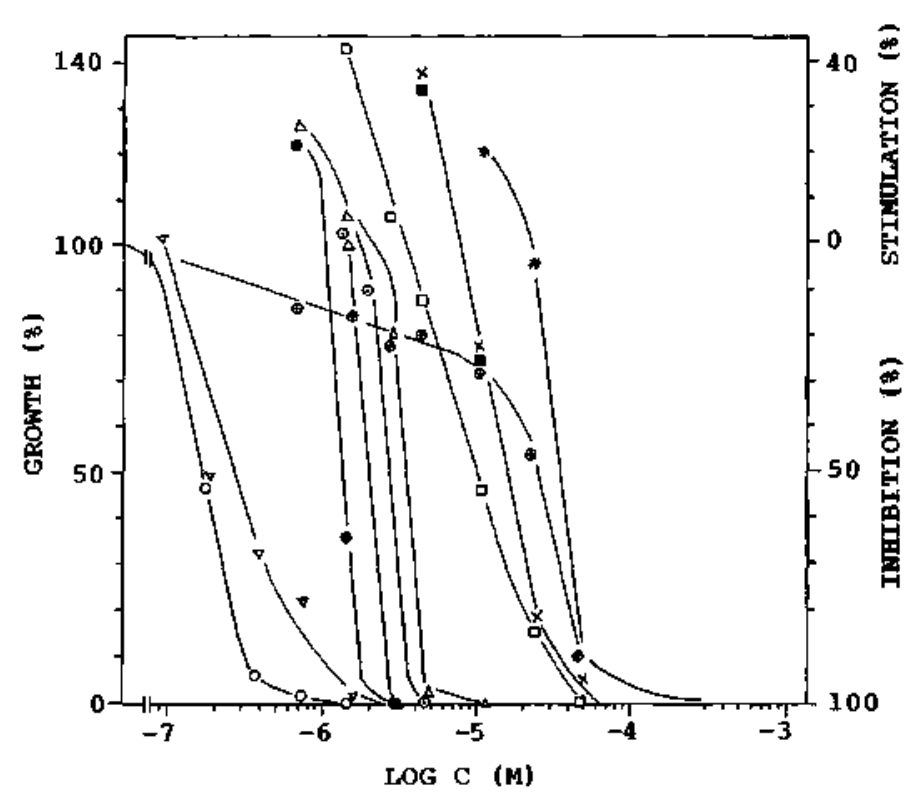

Fig. 12. Effect of thionins on bacterial and fungal pathogens. (O) Corynebacterium sepedonicum. ( $\nabla)$ Pseudomonas solanaceartm, (๑) Rosellinia necatrix, (4) Trichoderma viride, $(\odot)$ Aspergillus nidulans, $(\Delta)$ Fusaritum solant, $(\square)$ Fusarium sp. $78,(\mathbf{D})$ Fusarìum sp. 72, (×) Botrytis sp... (甲) Botrytis sp. B100, (*) Rhizoctonia solani (Molina and Fraile, unpubl.). A mixture of $\alpha$ - and $\beta$-thionins from wheat endosperm was used. Growth was determined by measuring absorbance at $492 \mathrm{~nm}$ and expressed as $\%$ of untreated controls.

Stimulation at low thionin concentrations was observed

Direct evidence of a defense role for the thionins is lacking at present. Although thionin mRNA is transiently induced in barley upon infection with Erysiphe graminis (Bohlmann et al., 1989) and a slightly different localization of thionins seems to occur in the cell walls of susceptible and resistant barley cultivars (Ebrahim-Nesbat et al., 1989), the resistance gene and the thionin genes are located in different chromosomes and the thionin mRNA is induced to similar levels in both susceptible and resistant cultivars. Furthermore, the pre-induction levels of thionins seem to be quite high, due to their low turn-over (Reiman-Philipp et al., 1989a).

\section{Conclusion and Perspectives}

Different types of thionins are quite abundant in different tissues of a given plant and the available distribution data suggest that this family of proteins might be ubiquitous in the plant kingdom. The fact that some thionin types are toxic to both bacterial and fungal pathogens and that thionin genes can be induced under stress conditions, including microbial infection, suggests 
that this protein family might have a role in plant defense. However, more direct evidence for this hypothesis will have to come either from the demonstration that some resistance trait and thionin genes cosegregate or from the study of transgenic plants expressing foreign thionin genes. If this protein family is ubiquitous, then the potential of thionin genes as targets for manipulation in breeding for disease resistance would largely depend on the specificity of natural and artificial protein variants, as well as in our ability to express them under different developmental programs and environmental situations.

The possibility of a non-defense biological function for thionins remains open and their suggested role as secondary thiol messengers merits further attention, especially after the experiments of Johnson et al. (1987), in which these proteins were assayed under more physiological conditions.

\section{Acknowledgements}

We thank D. Lamoneda and J. Garcia for technical assistance, and the Fundación Ramón Areces for support of our current work on the subject of this review.

\section{References}

Balls AK, Harris TH (1944) The inhibitory effect of a protamine from wheat flour on the fermentation of wheat mashes. Cereal Chem 21: 74-79

Balls AK, Hale WS, Harris TH (1942a) A crystalline protein obtained from a lipoprotein of wheat flour. Cereal Chem 19: 279-288

Balls AK, Hale WS, Harris TH (1942b) Further observations on a crystalline wheat protein. Cereal Chem 19: $840-844$

Bohlmann H, Apel K (1987) Isolation and characterization of cDNAs coding for leaf-specific thionins closely related to the endosperm-specific hordothionin of barley (Hordeum vulgare L.). Mol Gen Genet 207: 446-454

Bohlmann H, Clausen S, Behnke S, Giese H, Hiller C, Reimann-Philipp U, Schrader G, Barkholt V, Apel K (1988) Leal-specific thionins of barley-a novel class of cell wall proteins toxic to plant-pathogenic fungi and possibly involved in the defense mechanism of plants. EMBO J 7: 1559-1565

Brunger AT, Clore GM, Gronenborn AM, Karplus M (1986) Three-dimensional structure of proteins determined by molecular dynamics with interproton distance restraints: application to crambin. Proc Natl Acad Sci USA 83: 3801-3805

Brunger AT, Campbell RL, Clore GM, Gronenborn AG, Karplus M, Petsko GA, Teeter NM (1987) Solution of a protein crystal structure with a model obtained from NMR interproton distance restraints. Science 235: 1049-1053

Buchanan BB, Wolosiuk RA, Schurmann P (1979) Thioredoxin and enzyme regulation. Trends Biol Sci 4: 93-96

Carrasco L, Vazquez D, Hernandez-Lucas C, Carbonero P, Garcia-Olmedo F (1981) Thionins: plant peptides that modify membrane permeability in cultured mammalian cells. Eur J Biochem 116: 185-189 
Castagnaro A, Maranua C, Carbonero P, Garcia-Olmedo F (1992) Extreme divergence of a novel wheat thionin generated by a mutational burst specifically affecting the mature protein domain of the precursor. J Mol Biol (in press)

Clore GM, Brunger AT, Karplus M, Gronenborn AM (1986a) Application of molecular dynamics with interproton distance restraints to three-dimensional protein structure determination. A model study of crambin. J. Mol. Biol. 191: 523-551

Clore GM, Nilges M, Sukumaran DK, Brunger AT, Karplus M, Gronenborn AM (1986b) The three-dimensional structure of $\alpha 1$-purothionin in solution: combined use of nuclear magnetic resonance, distance geometry and restrained molecular dynamics. EMBO J 5: $2729-2735$

Coulson EJ, Harris TH, Axelrod B (1942) Effect on small laboratory animals of the injection of the crystalline hydrochloride of a sulfur protein from wheat flour. Cereal Chem 19: $301-307$

Ebrahim-Nesbat F, Behnke S, Kleinhofs A, Apel K (1989) Cultivar-related differences in the distribution of cell-wall-bound thionins in compatible and incompatible interactions between barley and powdery mildew. Planta 179: 203-210

Feng D-F, Doolittle RF (1987) Progressive sequence alignment as a prerequisite to correct phylogenetic trees. J Mol Evol 25: $351-360$

Fernandez de Caleya R (1973) Caracterización química y propiedades antimicrobianas de purotioninas. PhD Thesis, Universidad Politécnia de Madrid, Madrid, Spain

Fernandez de Caleya R, Gonzalez-Pascual B, Garcia-Olmedo F, Carbonero P (1972) Susceptibility of phytopathogenic bacteria to wheat purothionins in vitro. Appl Microbiol 23: $998-1000$

Fernandez de Caleya R, Hernandez-Lucas C, Carbonero P, Garcia-Olmedo F (1976) Gene expression in alloploids: genetic control of lipopurothionins in wheat. Genetics 83: 687-699

Fisher R, Behnke S, Apel K (1989) The effect of chemical stress on the polypeptide composition of the intercellular fluid of barley leaves. Planta 178: 61-68

Garcia-Olmedo F, Carbonero P, Jones BL (1982) Chromosomal locations of genes that control wheat endosperm proteins. Adv Cereal Sci Technol 5: 1-47

Garcia-Olmedo F, Carbonero P, Hernandez-Lucas C, Paz-Ares J, Ponz F, Vicente O, Sierra JM (1983) Inhibition of eukaryotic cell-free protein synthesis by thionins from wheat endosperm. Biochim Biophys Acta 740: 52-56

Garcia-Olmedo F, Carbonero P, Salcedo G, Aragoncillo C, Hernandez-Lucas C, Paz-Ares $J$, Ponz F (1984) Chromosomal location and expression of genes encoding low molecular weight proteins in wheat and related species. Kulturpflanze 32: 21-32

Garcia-Olmedo F, Rodriguez-Palenzuela P, Hernandez-Lucas C, Ponz F, Maraña C, Carmona MJ, Lopez-Fando J, Fernandez JA, Carbonero P (1989) The thionins: a protein family that includes purothionins, viscotoxins and crambins. Oxford Surv Plant Mol Cell Biol 6: $31-60$

Gausing K (1987) Thionin genes specifically expressed in barley leaves. Planta 171: 241-246

Hendrickson WA, Teeter MM (1981) Structure of the hydrophobic protein crambin determined directly from the anomalous scattering of sulphur. Nature 290: 107-113

Hernandez-Lucas C, Fernandez de Caleya R, Carbonero P (1974) Inhibition of brewer's yeasts by wheat purothionins. Appl Microbiol 28: 165-168

Hernandez-Lucas C, Royo J, Paz-Ares J, Ponz F, Garcia-Olmedo F, Carbonero P (1986) Polyadenylation site heterogeneity in mRNA encoding the precursor of the barley toxin $\alpha$-hordothionin. FEBS Lett 200: 103-105

Johnson TC, Wada K, Buchanan BB, Holmgren A (1987) Reduction of purothionin by the wheat seed thioredoxin system. Plant Physiol 85: 446-451 
Jones BL, Meredith P (1982) Inactivation of alpha-amylase activity by purothionins. Cereal Chem 59: 321

Konopa J, Woynarowsky JM, Lewandowska-Gumieniak M (1980) Isolation of viscotoxins. Cytotoxic basic polypeptides from Viscum album L. Hoppe Seylers Z Physiol Chem 361: 1525-1533

Kramer KJ, Jones BL, Speirs RD, Klassen LW and Kammer AE (1979) Toxicity of purothionin and its homologues to the tobacco hornworm, Manduca sexta (L.) (Lepidoptera: Sphingidae). Toxicol Appl Pharmacol 48: 179-183

Kwak KB, Lee YS, Suh SW, Chung CS, Ha DB, Chung CH (1989) Purothionin from wheat endosperm reversibly blocks myogenic differentiation of chick embryonic muscle cells in culture. Exp Cell Res 183: 501-507

Nakanishi T, Yoshizumi H, Tahara S, Hakura A, Toyoshima K (1979) Cytotoxicity of purothionin-A on various animal cells. Gann 70: 323-326

Nose Y, Ichikawa M (1968) Studies on the effects of flour extract on baker's yeast. J Ferment Technol 46: 915-925

Ohtani S, Okada T, Kagamiyama $H$, Yoshizumi $H$ (1975) The amino acid sequence of purothionin A, a lethal toxic protein for brewer's yeasts from wheat. Agricult Biol Chem 39: $2269-2270$

Ohtani S, Okada T, Yoshizumi H, Kagamiyama $\mathrm{H}$ (1977) Complete primary structures of two subunits of purothionin A, a lethal protein for brewer's yeast from wheat flour. $J$ Biochem 82: 753-767

Okada T, Yoshizumi H (1970) A lethal toxic substance for brewing yeast in wheat and barley. II. Isolation and some properties of toxic principle. Agricult Biol Chem 34: $1089-1094$

Okada T, Yoshizumi H (1973) The mode of action of toxic protein in wheat and barley on brewing yeast. Agricult Biol Chem 37: 2289-2294

Okada T, Yoshizumi H, Terashima Y (1970) A lethal toxic substance for brewing yeast in wheat and barley. I. Assay of toxicity on various grains, and sensitivity of various yeast strains. Agricult Biol Chem 34: 1084-1088

Ozaki Y, Wada K, Hase T, Matsubara H, Nakanishi T, Yoshizumi H (1980) Amino acid sequence of a purothionin homolog from barley flour. J Biochem 87: 549-555

Ponz F, Paz-Ares J, Hernandez-Lucas C, Carbonero P, Garcia-Olmedo F (1983) Synthesis and processing of thionin precursors in developing endosperm from barley (Hordeum vulgare L.). EMBO J 2: 1035-1040

Ponz F, Paz-Ares J, Hernandez-Lucas C, Garcia-Olmedo F, Carbonero P (1986) Cloning and nucleotide sequence of a cDNA encoding the precursor of the barley toxin $\alpha$ hordothionin. Eur J Biochem. 156: 131-135

Reimann-Philipp U, Behnke S, Batschauer A, Schafer E, Apel K (1989a) The effect of light on the biosynthesis of Jeaf-specific thionins in barley, Hordeum vulgare. Eur $\mathbf{J}$ Biochem 182: 283-289

Reimann-Philipp U, Schrader G, Martinoia E, Barkholt V, Apel K (1989b) Intracellular thionins of barley. A second group of leaf thionins closely related to but distinet from cell wall-bound. J Biol Chem 264: 8978-8984

Rodriguez-Palenzuela P, Pintor-Toro JA, Carbonero P, Garcia-Olmedo F (1988) Nucleotide sequence and endosperm-specific expression of the structural gene for the toxin $\alpha$ hordothionin in barley (Hordeum vulgare L.). Gene 70: 271-281

Samuelsson G (1974) Mistletoe toxins. Syst Zool 22: 566-569

Sanchez-Monge R, Delibes A, Hernandez-Lucas C, Carbonero P, Garcia-Olmedo F (1979) Homoeologous chromosomal location of the genes encoding thionins in wheat and rye. Theor Appl Genet 54: 61-63 
Stuart LS, Harris TH (1942) Bactericidal and fungicidal properties of a crystalline protein isolated from unbleached wheat flour. Cereal Chem 19:288-300

Tahara S, Hakura A, Toyoshima K, Nakanishi T, Yoshizumi H (1979) A new method for titration of murine leukemia virus using purothionin A. Virology 94: 470-473

Vernon LP, Evett GE, Zeikus RD, Gray WR (1985) A toxic thionin from Pyrularia pubera: purification, properties, and amino acid sequence. Arch Biochem Biophys 238: 18-29

Wada K, Buchanan BB (1981) Purothionin: a seed protein with thioredoxin activity. FEBS Lett 124: $237-240$

Whitlow M, Teeter MM (1985) Energy minimization for tertiary structure prediction of homologous proteins: $\alpha$-purothionin and viscotoxin $\mathrm{A} 3$ models from crambin. J Biochem Struct Dynam 2: 831-848

Woynarowski JM, Konopa J (1980) Interaction between DNA and Viscotoxins. Cytotoxic basic polypeptides from Viscum album L. Hoppe Seylers Z Physiol Chem 361: 1535-1545 